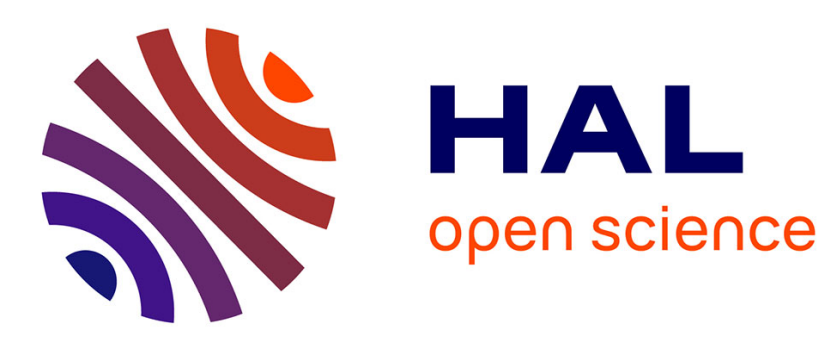

\title{
The Role of the Philosophy of Technology in French-Language Studies of Video Games
}

\author{
Mathieu Triclot
}

\section{To cite this version:}

Mathieu Triclot. The Role of the Philosophy of Technology in French-Language Studies of Video Games. French Philosophy of Technology, 29, pp.101-118, 2018. halshs-02054061

\section{HAL Id: halshs-02054061 https://shs.hal.science/halshs-02054061}

Submitted on 1 Mar 2019

HAL is a multi-disciplinary open access archive for the deposit and dissemination of scientific research documents, whether they are published or not. The documents may come from teaching and research institutions in France or abroad, or from public or private research centers.
L'archive ouverte pluridisciplinaire HAL, est destinée au dépôt et à la diffusion de documents scientifiques de niveau recherche, publiés ou non, émanant des établissements d'enseignement et de recherche français ou étrangers, des laboratoires publics ou privés. 
Triclot M. (2018) The Role of the Philosophy of Technology in FrenchLanguage Studies of Video Games. In: Loeve S., Guchet X., Bensaude Vincent B. (eds) French Philosophy of Technology. Philosophy of Engineering and Technology, vol 29. Springer, Cham 


\title{
The role of the philosophy of technology in French-language studies of video games
}

Mathieu Triclot, Université Bourgogne Franche-Comté, Laboratoire Irtes-Récits

Translation by Nina Bogin, Université de Technologie de Belfort-Montbéliard

\begin{abstract}
This paper analyzes the role played by the philosophies of technology in the development of French-language studies devoted to video games. This intellectual tradition is well represented within the field, in a variety of forms which are characteristic of the main tendencies in the French-language philosophy of technology. The field of games studies allows us to compare these different approaches to a single object. We analyze the specificities of the Frenchlanguage field, its theoretical options, and the role played by the philosophy of technology in its points of divergence from the dominant tendencies in game studies. We specifically discuss four studies located at the intersection between philosophy of technology and video games studies: the reference to Simondon in Etienne Perény's works; the framework of « technological macro-systems » (Gras) according to Raphaël Koster; the alliance between philosophy of technology and phenomenology in the work of Elsa Boyer (Husserl, Derrida and Stiegler); and lastly, the utilization of the "philosophy of technical environments" (Beaune) in our own Philosophy of video games.
\end{abstract}

\section{Introduction}

This paper analyzes the role played by the philosophies of technology in the development of Frenchlanguage studies devoted to video games. Since about 2005, numerous studies in this field have been published in French. These studies show considerable differences compared with the tradition of English language game studies and the way it has developed, in particular in the United States and northern Europe (Rueff, 2008 ; Zabban, 2012).

The philosophy of technology has played an important role in the constitution of this French-language field of study. Not only is this particular intellectual tradition well represented within the field, but it is present as well in a variety of forms which are characteristic of the main tendencies in the French-language philosophy of technology. From this point of view, therefore, the field of games studies is thus of particular interest inasmuch as it allows us to compare these different approaches to a single object.

The debates taking place within French-language video game studies thus echo older quarrels concerning the manner of apprehending the technical domain. Lastly, we must also ask ourselves to what extent video games help to bring about the renewal of these intellectual traditions and the fostering of new questions, methods, or investigative practices.

The existence of a relatively autonomous field of "game studies à la française" provides a particularly interesting basis for investigating the contemporary dynamics in the humanities, between the internationalization of research practices and the shaping of knowledge by local intellectual traditions and institutions. Philosophy of technology has thus contributed to the opening of new paths for games studies, based on intellectual traditions that were rarely solicited or simply unknown in the English-language field. This paper has the particularity of being written from the point of view of an actor in the field. It proposes a combination of this actor's account, with the limits such a point of view implies, and an epistemological study of the way this field of knowledge has developed.

We will begin by examining the characteristics which serve as the foundation for video games as an object of research and which explain the diversity of available approaches. Secondly, we will analyze the specificities of the French-language field, its theoretical options, and its points of divergence from the dominant tendencies in game studies. Thirdly, we will specifically discuss four studies located at the intersection between philosophy of technology and video games studies : the reference to Simondon in Etienne Perény's works; the framework of « technological macro-systems » (Gras) according to Raphaël Koster; the alliance between philosophy of technology and phenomenology as demonstrated by the question of artificial perception in the work of Elsa Boyer (Husserl, Derrida and Stiegler); and lastly, the utilization of the "philosophy of technical environments" (Beaune) in our study Philosophie des jeux video (The Philosophy of video games).

\section{Theorizing video games}

That a French-language field of video games studies should have seen the light of day, with a certain 
autonomy in relation to the English-language field, is due in part to the difficulties which affect the development of video games as an object of research. The first of these difficulties comes from the blurring of categories under which video games can be apprehended. Indeed, video games are distinguished by a constitutive heterogeneity, straddling the fields of technology, art and culture, sports and competition, pictures and fiction, the world of toys, etc. (Sidre, 2014). The video game thus offers a multiplicity of "theoretical angles", and the disciplines which can lay claim to it are numerous.

Moreover, this effect of categorial heterogeneity is reinforced by the scale and range of the video games domain. Video games appeared in the early 1960s in the first laboratories dedicated to the nascent field of computer science in the United States (Donovan, 2010; Triclot, 2012). This history of more than fifty years has aggregated a considerable quantity of material, including the games themselves, a large variety of graphic forms, peripherals, and software and hardware solutions, as well as secondary sources (magazines, commercial documentation, advertising, etc). Today, video games represent one of the main cultural practices in France, so much so that it is difficult to define the whole range and diversity of ways of playing (Boutet, 2012; Coavoux, Rufat, Ter Minassian, 2014). Moreover, video games cannot be artificially separated from other cultural practices or from other recreational activities (Berry, 2012). The field is thus immense.

Lastly, a final element weighs upon the development of video games as an object of research : the fact that video games are a part of popular culture as a product of cultural industries as well as of consumer culture (Kline, Dyer-Witheford, de Peuter, 2003). The strategies necessary to negotiate this deficit of legitimacy represent an important aspect of the epistemological trajectory of the field and offset the risk, admittedly symbolic but always present, that the seriousness of the research might be contaminated by the futile character of its object (Rufat, Ter Minassian, 2012). Furthermore, such academic research does not arrive on virgin territory. It has to contend with a mass of already available knowledge, from the industry itself, the players, technical training programs, etc. The way in which the division between academic knowledge and lay knowledge is negotiated is thus one of the essential coordinates of the field. Indeed, Anglo-Saxon game studies have evolved in close conjunction with the professional knowledge of game design (Juul, 2005, Bogost, 2010).

\section{Constitution of the French-language field}

These characteristics allow us to take stock of the diversity of current epistemological strategies which serve to make video games into an object of knowledge. In the case of the French-language field, several other dimensions must be taken into consideration. The first is the fact of "lateness". Indeed, "French research has lagged one or two decades behind Anglo-Saxon scientific production in the field." (Amato, Perény, $2008: 4$ ). "In France, research in game studies is both more recent and less structured than in Anglo-Saxon countries." (Rufat, Ter Minassian, 2012 : 8). This time-lag effect has encouraged a reflective and critical approach to the Anglo-Saxon corpus.

If the publication of the online review "game studies" in 2001 is a good indicator of the structuring of the English-language field (Aarseth, 2001), then it must be admitted that French-language studies appeared with a time-lag of several years. But beyond the factor of mere lateness, French studies do not benefit from the same level of organization, with a space of shared discussion. The first studies in France were divided between information and communication science (SIC), with three Ph.D. dissertations by Vincent Mabillot (2000), Sébastien Genvo (2006) and Etienne Armand Amato (2008); computer science, with the work of Stéphane Natkin (2004); and sociology, with the pioneering work of Pierre Bruno (1993), the dissertation by Laurent Tremel on role-playing games (2001), the book edited by Nicolas Auray and Sylvie Craipeau (2003), and the dissertation by Manuel Boutet (2006).

The case of information and communication science is particularly representative, insofar as the video game object was regularly investigated in this domain, starting in 1983 (Querzola, Verebelyi, 1983), but always on the margins, as an example to illustrate other dynamics, without being elaborated for itself. Consequently, when referring to the period between 1999 and 2004 when many video games were studied in seminars, Perény and Amato emphasize that "it is surprising that despite its public recognition, the video game was not at that time able to constitute an object of research as such. Rather, it allowed researchers to investigate and explore the significant variations in interactivity, to illustrate the paradoxes of interactive texts and to test the validity of a vocabulary centered on interactivity and participation.” (Amato, Perény, 2011).

The French-language field experienced a breakthrough around 2010, as indicated by an increase in the 
number of publications and the appearance of new disciplines and new forms of exchanges in the field. The organizing of day-long seminars "game studies? à la française!" starting in 2011, is an indication of the recognition of this turnaround as the moment when "shirts were tucked in", when "the 'casual style' of the earlier studies would soon no longer prevail in disciplines where video games research are now recognized" (Amato; Boutet, Gaon, 2011).

This period corresponded to a number of publications : of dissertations by Alexis Blanchet (2010) and Vinciane Zabban (2011), of a collective work edited by Samuel Rufat and Hovig Ter Minassian under the performative title Les jeux video comme objet de recherche (Video games as an object of research) (2011), and of Philosophie des jeux video (The Philosophy of video games) (Triclot, 2011). A particularity of this French editorial context is that in addition to the academic production, a type of "fan culture" publication also appeared, notably with the work of Pix'n Love editions, who published journalistic monographs which served as materials for research and occasionally academic studies (Blanchet, 2010, Audureau, 2014).

\section{Game studies or play studies}

The late development of the French-language field tended to foster critical attitudes to Anglo-Saxon studies. The article by Vinciane Zabban devoted to the structuring of Anglo-Saxon game studies helps to shed light, by contrast, on the differences in positioning characteristic of the French-language field (Zabban 2012). According to Zabban, game studies are based on two tightly linked commitments : the primacy given to the game itself (rules and settings) over ways of playing (recreational practices and attitudes), and the choice of the development of a new discipline (ludology) supported by an argument concerning the singularity of games.

It seems to us that the French-language field is characterized by diametrically opposed theoretical commitments : studies of play rather than game studies, and the maintaining of the context of existing disciplines rather than the demand for a ludology.

The most obvious point of divergence and the most prevalent in French-language studies is the primacy given to the study of play as experience and practice in contrast to an internalist analysis of games centered on design and systems. This attention to the game as the activity of players reflects the importance of the socio-anthropological context (Berry, Boutet, Coavoux, Koster, Rufat, Ter Minassian, etc). It also coincides with historical studies which examine the material, technical and economic dimensions of gaming practices (Blanchet, Sidre, Perény). This orientation brings the French-language studies close to the positions presented by Play and Culture review or to the anthropological studies by Taylor, Boellstorf and Servais.

It is interesting to note that the primacy given to play is rooted in the French-language tradition. While the work of Roger Caillois represents a major reference in international studies, benefiting from translations from 1961 onward, the writings of the philosopher Jacques Henriot or of the psychologist Jean Chateau, for example, are unknown in the field of international game studies. Yet these writers all move towards a definition of play as an activity, which gives priority to the habits as well as to the attitudes of the players. The Caillois, Henriot and Chateau definition minimizes the role of rules, in a break with the formalistic definition of games widely shared in contemporary game studies but which can also be found within the French-language structuralist tradition, notably in Lévi-Strauss (Wendling, 2010).

The effects of tradition and transmission thus come fully into play. Not only is this corpus accessible to the French-language reader, but its authors played a role in the structuring of the research. Jacques Henriot in particular was the founder of the "sciences du jeu" (play sciences) department at the University of Paris 13, a department which is still active, through its Experice laboratory, in the domain of the science of education and the sociology of games (Brougère, 2003).

On the other hand, the question of the uniqueness of the ludic domain, and its corollary, the demand for an independent discipline, is open to debate. While the passage through existing disciplines is clearly affirmed by some researchers (Rufat, Ter Minassian, 2012), other actors in the French-language field are more sensitive to arguments of singularity. This is notably the case among researchers in the domain of information and communications science. Amato's research, for example, aims at characterizing the uniqueness of video games as a "cybermedium", refusing to dilute the question of apparatus in the potentially infinite number of possible uses. But this reevaluation of the technical apparatus does not in any way eliminate the reference to play and to forms of experience, especially concerning the question of avatars (Amato, Perény, 2010). 
Genvo's work stems from an analogous position : although he is certainly one of the researchers closest to Anglo-Saxon-style game studies through the importance given to game design and the demand for a ludological perspective, his ludology is nevertheless based on the French tradition focused on play, particularly in Henriot (Genvo, 2013).

\section{Philosophy and philosophy of technology}

The studies undertaken from the point of view of the academic discipline of philosophy first appeared during the second wave of French-language game studies, around 2010. We can emit the hypothesis that the lack of legitimacy of the video game played a crucial role in this slow recognition, the gap between legitimate culture and popular culture being undoubtedly at its maximum.

The emergence of these philosophical studies occurred in the absence of a unified framework. The approaches are characterized by their diversity, representative of the French-language philosophical domain : aesthetics (Olivier Robert, Thomas Morisset, Dork Zabunyan); phenomenology (Elsa Boyer, Brice Roy); epistemology (Martine Robert), and philosophy of technology (Elie During, Mathieu Triclot).

Philosophical references, however, extend beyond the philosophical field to inform other disciplines. Thus the "gameifying" (ludicization) model is presented in Genvo's work in reference to Deleuzian "assemblage", the description of the concretization process of interactive images as found in Perény is based on Simondon's categories, the socio-anthropology of recreational pleasures presented by Koster is founded on a reference to the "technological macro-systems" of Alain Gras, and the observing of game situations in the anthropological studies of Manuel Boutet is inspired by pragmatist philosophy.

Among these studies of a philosophical orientation, we have chosen to present a limited corpus based on the double criteria of the importance given to the philosophy of technology and the state of achievement (publication or dissertation defense). We have thus selected the following four approaches : the work accomplished by Perény with reference to Simondon; Koster's socio-anthropological study of recreational pleasures, included in the work of the CETCOPRA laboratory; the phenomenology of artificial perception developed by Boyer, informed by a critical re-reading of Husserl, Derrida and Stiegler; and lastly, the analysis of "systems of experience" in video games in Triclot's work which continues the tradition of "the philosophy of technical environments". Perény and Koster's work is of particular interest because it derives from associated fields - science of information and communication, sociology, anthropology - while attributing a central position to the philosophy of technology.

These works, while illustrating the diversity of available options in the French-language field, also permit us to compare the productivity of these different theoretical frameworks. In order to facilitate discussion of these studies, we will analyze each of them through the prism of a common reading grid : key concepts and theoretical innovations, paradigmatic examples, relationship to empirical materials, number of video games mentioned, criticism of Anglo-Saxon game studies, and finally, blind spots inevitably produced by the conceptual framework. The purpose will be to question and highlight the theoretical styles, whose differences are not limited solely to the notions activated, but also depend on writing practices, types of depiction (diagrams, tables, iconography), and the terrain and objects which have been given priority.

Beyond the diversity of approaches and the theoretical effects thus produced, the involvement of the philosophy of technology on the video game terrain also raises the question, we believe, of the relationship between the philosophical work and the empirical data. Indeed, the works mentioned above enter fully into the scope of French-language studies of games, where we have already seen that they favor the notions of play, forms of experience, and the historicity of phenomena in its technical and material aspects. Within this field, philosophy of technology occupies a position of exchange with the other disciplines in the humanities. Once the philosophy of technology is structurally defined by a domain of objects issuing from concrete human activities, the question of the articulation between philosophy and other knowledge approaches arises. What is the philosophy of technology? Is its role solely to provide an epistemological framework for historiography? What space, more or less autonomous, can it preserve in relationship to the perspective of a socio-anthropology? How can the role of philosophy of technology be negotiated within the approaches to knowledge aimed at an empirical content? 


\begin{tabular}{|l|l|l|l|l|}
\hline & Perény & Koster & Boyer & Triclot \\
\hline Concepts & Concretization & $\begin{array}{l}\text { Technical macro- } \\
\text { systems }\end{array}$ & $\begin{array}{l}\text { Artificial } \\
\text { perception }\end{array}$ & $\begin{array}{l}\text { Systems of } \\
\text { experience }\end{array}$ \\
\hline Paradigms & $\begin{array}{l}\text { Aspen Movie } \\
\text { Map }\end{array}$ & $\begin{array}{l}\text { Network games, } \\
\text { museology }\end{array}$ & $\begin{array}{l}\text { Serious games, } \\
\text { Farocki's films }\end{array}$ & $\begin{array}{l}\text { Historical shift } \\
\text { from computer } \\
\text { gaming in the } \\
\text { universities to the } \\
\text { arcades }\end{array}$ \\
\hline Terrain & History & Interviews & Phenomenology & History \\
\hline Number of games & $<5$ & around 30 & $<5$ & around 100 \\
\hline $\begin{array}{l}\text { Criticism of game } \\
\text { studies }\end{array}$ & $\begin{array}{l}\text { Ignoring of the } \\
\text { technical making } \\
\text { of images }\end{array}$ & $\begin{array}{l}\text { Ignoring of } \\
\text { experience and } \\
\text { social context }\end{array}$ & Not mentioned & Ignoring of play \\
\hline Blind spots & Uses & Techniques & $\begin{array}{l}\text { Diversity of } \\
\text { situations }\end{array}$ & $\begin{array}{l}\text { Semiology and } \\
\text { game design }\end{array}$ \\
\hline
\end{tabular}

The concretization of interactive images

Images interactives et jeu video : de l'interface conique à l'avatar numérique (Interactive images and video games : from iconic interface to digital avatar) by Etienne Perény appeared in 2013. This study reviews a thirty-year research trajectory. As a member of the Paragraphe laboratory (Paris 8), a pioneering research center for the computerization of texts and writing, in 1983 Perény founded the Atelier de Vidéomatique, specialized in the study of interactions with images. The central thesis of the book is expressed in a direct reference to Simondon : video games constitute the "concretization" of the interactive image, "this interactive evolution of the image only being fully achieved via the generalization of digital avatars." (Perény, $2013:$ 7)

The debt to Simondon throughout the book concentrates on three main points. The first consists in supporting the demand for a return to the technical object itself, in the form of a nuanced and well-informed description of its genesis and of its "concretization" process. This genetic approach calls upon Simondon's ontology of technology : "technical element, object, individual, and ensemble". This perspective introduces a critical distance from the ludological tendency in Anglo-Saxon game studies as well as from the socioanthropological tendency in French-language game studies. Perény thus proposes a model which distinguishes, in several concentric circles, "pure technicity" from secondary dimensions which, according to Simondon's theoretical lexicon, are a part of "cultural over-determination" . "The playability specific to the interactive (video) image" is placed at the center of the model.

The second major debt to Simondon concerns the notion of "technological culture". It is not only a question of "refusing the facile opposition between culture and technology" but also of bringing about, in an optimistic inflection of Simondon's thinking, a transformation in the relationship to technicity, due to the computerization of societies. Perény defends the idea of a spreading of technological culture via popular culture, thanks partly to hackers who "give voice to the code" but also, on a much wider level, to players who "experience coupling with the electronic signal". Games reintroduce into the general culture "the awareness of the nature of machines, of their mutual relationship, of their relationship with man and with the values implied by these relationships", according to the wish expressed by Simondon himself.

The cultural valorization of these new forms of coupling with computers leads us to the notion of "associated environments", the third concept in Simondon's theories on technology which inform Perény's reflections. Perény sees computer networking and the generalized use of avatars as the basis of a new "technological environment” which insures and intensifies man-machine couplings.

This is a crucial point in that it illuminates the manner in which Simondon's categories are rethought in Perény's essay. "Concretization”, especially, appears less as a process of functional over-determination than as an elaboration of an associated environment. Accordingly, Perény does not offer many analyses of concretization, along the lines of the paradigmatic study of the motor cooling fins presented by Simondon. Yet descriptions of this sort would be possible, by analyzing, for example, the manner in which the first programmers were able to push the capacities of their machines to the maximum, while expertly taking advantage of their technical limitations (Montfort, Bogost, 2009). In this way, "concretization” as seen in 
Perény is less about technological individuals in and of themselves than about the operator-machine relationship.

This first transformation can be understood in conjunction with the fundamental question of the essay, that of the effects of the apparatus on the subjects, analyzed under the category of "coupling". In a departure from Simondon's thesis, Perény introduces a question typical of a Leroi-Gourhan type of artificialist anthropology concerning the transformations of subjects linked to the technological environment. As Perény recognizes, this question necessitates the contribution of other references and theoretical contexts. To this end, as a kind of logical "supplement” to Simondon's theories, Perény refers to the work of Akrich, Latour, Deleuze and Guattari. We can nevertheless wonder to what extent these additions lead to a transformation of the Simondon framework. Perény modestly presents his essay as a simple "application” of Simondon's concepts, but its trajectory raises questions about and touches on research areas that invite us not only to "complete" the initial framework, but also to introduce conceptual innovations that would inflect it from within.

One of Perény's most remarkable concepts, therefore, is the idea of "impure synthesis". The impurity of synthesis can be understood, in relation to the interactive image, as a polemic against the idea of the purely textual or numerical character of the image, and as a decisive reevaluation of the numerical-analogical coupling in the interactive image. That such a synthesis requires being described as "impure" at the end of the concretization process raises doubts concerning the strict application of Simondon's theoretical framework.

Moreover, it is impossible not to wonder to what extent the process of concretization complies with elements like playing and hacking, which concern re-appropriations, more or less gratuitous, of the technical object. Considering the video game as the product of a Simondonian concretization process results in a paradoxical thesis, since video games can be seen rather as an outstanding example of cultural over-determination, submitting computers to an unexpected use.

The Simondon framework produces a number of blind spots : the links between video games, counter-culture and hacker culture, and the fact that this same hacker culture encounters a certain resistance on the part of laboratories, are all left out of the discussion (Weizenbaum, 1976; Markoff, 2005). Yet we must ask ourselves if these historical elements are only a marginal record (which can be treated as cultural over-determination) or if they play a determining role. The fact that French computer science, for example, has not developed a game culture, with the exception of a handful of literary programs, even while American games were known, raises questions.

These blind spots are no doubt the price to pay for the constitution of a new area of intelligibility. The return to the apparatus and to its fundamental effects thus allows for a clarification of the "holding power" of the interactive image (Turkle, 1984). The description of a new relationship of play to machines, thanks to the incorporation of body patterns, as an element of impure synthesis, seems highly pertinent, and in keeping with the descriptions we can find in Boyer's writings. Perény describes a "new business" with images, based on "body memo inscriptions of sensory-motor and kinesthetic origins, produced by the very act of interaction, and which are imprinted on the memory of the subject."

Video games are based on these highly powerful interactive effects which Pereny's studies illuminate in a remarkable manner. But the relationship between concretization, play, appropriation, and usage undoubtedly pushes the Simondon framework "to the wall”, to use Elie During’s expression quoted by Perény (During, 2006), and encourages the development of a form of conceptual innovation within Simondon's system.

\section{Socio-anthropology of the video-gaming experience}

Raphael Koster's dissertation "Le jeu video comme manière d'être au monde: socio-anthropologie de l'expérience vidéoludique" (The video game as a way of being in the world : the socio-anthropology of the video-ludological experience), defended in March 2013, offers a counterpoint to Perény's work. Like Perény's studies, it provides a form of alliance between philosophy of technology and a second discipline, that of sociology. But while the philosophical references are less developed, both numerically and epistemologically, than in Perény's analyses, Koster's dissertation is nevertheless representative of a trajectory which begins in philosophy, Koster's original discipline, and moves toward socio-anthropology.

This form of alliance between the philosophy of technology and sociology is representative of the work developed by the CETCOPRA laboratory (Gras, Bensaude-Vincent, Guchet). The thesis follows a counter- 
trajectory to that of Perény : it begins not from techniques of the image, but from players; it attempts to characterize pleasures and experiences in order to assess them according to more general standards or structures, those of the "society of technicity" or "technical macro-systems".

These two concepts are explicitly borrowed from the writings of Alain Gras, the founder and director of the CETCOPRA laboratory. "The use of the notion of 'technical macro-systems' by Alain Gras allows for the characterization of cultural meanings attached to the organization of the society of technicity, 'the ways of being in the world' of technical macro-systems. (...) Each technical macro-system can thus be attached to anthropological values which determine ways of thinking, feeling and acting” (Koster, 2013 : 119). The task, based on descriptions of video game experiences provided by players in a series of highly enriching interviews (149 interviews), is thus to decrypt the normative frameworks and symbolic values which are the basis of such game practices.

These standards and values are masked in the game experience, which implies a form of "illusion" and "forgetting of technical aspects" (Guchet, 2005). "The pleasure of the game (...) is a kind of illusion : it is necessary to forget the process of the object's conception in order to concentrate on the final result (...). The transparency of the object keeps its usage at a distance from the veritable political and social issues which govern its conception, its production, and its commercialization. (Koster, 2013 : 114). This epistemological program does not, however, lead to a critical sociology which would seek to stalk myth and illusion on the part of the player, but to a "sociology of uses" which attempts to understand "how we play the games", the symbolic values gaming relies upon, and especially the prevalence given to the sensations and to the spectacular, arising from the industrialization of leisure activities.

The theoretical effort is thus diametrically opposed to that provided in Perény's work : it issues from "social over-determination" rather than from the intrinsic logic of technical concretization. The reference to Simondon is, in fact, of a critical nature : "the 'appropriation' of the technical object observed in the sociology of uses goes beyond the simple framework of 'a margin of indetermination' of the technical object conceptualized by Simondon, to take into account the cultural significations which the user attaches to his practice” (Koster, 2013 : 118).

This symmetrical effect can also be observed in "blind spots", insofar as technicity is not referred to in the analysis. It is above all a question of "observing in a tangible way the subjective manifestations of leisure activities and of connecting them to cultural patterns and to wider frameworks." Through the interviews, the analysis thus demonstrates several modalities of these leisure activities : mastery but also internalization and domestication of the constraints of the apparatus, immersion centered on "sensory pleasure, deployment of the imagination, and the advent of new forms of sociability".

\section{Phenomenology of artificial perception}

Elsa Boyer's work takes us to more speculative terrain, at a distance from the empirical dimension and disconnected from the sociology of uses. This return to philosophy is distinguished first of all by the object of the investigation, which focuses on the transcendental structures of conscience from a phenomenological perspective. Above all, it is concerned, along with "artificial perception", with the "auto-constitution of the flux of conscience" and with what it contains of exteriority and of technical prostheses. This discussion is pursued through a critical re-reading of the works of Husserl, Derrida and Stiegler.

In other words, video games in their empirical dimension do not constitute the first object of investigation. Similarly to the work of Pereny, the generalizing force of the study and the questioning of the artificialization of perception rely on a limited group of object-paradigms. In contrast to applications like the Aspen Movie Map found in Perény, Boyer proposes the work of the filmmaker Harun Farocki centering on the American army's use of serious games. These paradigms lead us away from video games as an object of mass consumption.

The video game appears in Boyer's analysis as one of the particular cases of "conflicts of perception” analyzed by Husserl : in addition to the ordinary perception of the player's immediate environment, the world of play superimposes itself, proposing a coherent universe with which to interact. However, the conflict between these two perceptions cannot be easily resolved according to the model of perceptive illusion, where two contradictory perceptions are briefly able to cohabit. Nevertheless, this conflict resembles other situations, such as daydreaming or free association of images within which, to quote Husserl, I let myself be drawn towards a "quasi-life". "Video game images provide visibility to an area 
which lies somewhere between technical apparatus, hallucination and fiction, which Husserl questions without confronting.” (Boyer, 2015 : 18).

We are dealing here with a project in which the video game object encourages us not only to reevaluate certain philosophical descriptions, but also to rethink the place of technology in phenomenology at the level of structures of consciousness. The video game appears first as an unthinkable object for phenomenology, in which it plays the role of intruder par excellence, in the name of the joint exclusion of the non-originary in perception, technology as a mode of rationality bogged down in an intra-worldly perspective, and objects of popular culture.

But Derrida's and Stiegler's perspectives are also criticized for their difficulty in accounting for what is truly of a conflicting nature in the artificial perspective. Stiegler, in an alliance with Simondon, describes the technological dimensions of the temporal constitution of consciousness. But he prefers the critical perspective of "synchronization of stream of consciousness" provided by the mass media. This notion of synchronization can indeed nurture our reflection on video games, but it does not account for the totality of perceptive situations, the discrepancies and de-synchronizations which can be observed in artificial perception.

The last chapters thus propose an unexpected return to Husserl based on the existence of these extreme cases, which are examined incidentally within the framework of phenomenology, but which invite us to rework the Husserlian theoretical framework from within. Boyer notes several situations and objects : the theater and aesthetic perceptions, wax museums, tinted glasses, stereoscopes, etc.

The examination of these extreme cases leads to a remarkable description of the sort of "constructed hallucination " which occurs in video games, when the perception of images is coupled with the feeling of being present in a real world. Video games retain the traits of the image freed of fantasy or of the fixity of the stereoscope. When Husserl evokes the imagining of a "Mars world", he explains that "it will be necessary to have power over sensitive fields, to be capable of changing the groups of phenomena " so that the situation of conflict cannot be easily resolved, according to the model of the return to an originary perception.

"Contrary to the examples of foreign perceptive fields used by Husserl, video games allow us to act directly on sensitive fields; they create a coherent sequence while the avatar can eventually serve as the intermediary for judgment and will. The video game thus offers, within the continuously varying limits provided by the program and the graphics used by the developers, a "quasi-life" inside a world which plays out across several different media and supports.” (Boyer; 2015 : p. 202)

Elsa Boyer's approach thus permits her to perceptively describe the superimpositions between different modes of presence in the video games situation. This superimposition culminates in a form of unresolved "conflict of perceptions", which reaches a crisis-point in "the untenable opposition between the originary and the non-originary" characteristic of the Husserlian philosophy.

We can nevertheless question the knowledge project of this "local phenomenology". It has the obvious advantage of circumscribing a unique area for philosophy : that of the study of the forming of consciousness. Aside from the fact that the borderline with psychology as an empirical science is subject to debate, we can also wonder to what extent an articulation with empirical knowledge is possible. In other words, does not the examination of concrete game situations, in their very diversity, inevitably lead us away from the transcendental framework?

This is in fact one of the reproaches made by Boyer to Stiegler's work: that he moves from the strictly transcendental perspective of the heterogeneity of flow of consciousness to a reflection on the "exteriorization" of processes of consciousness, in the anthropological manner of Leroi-Gourhan. The meeting-point between phenomenology and philosophy of technology is situated on particularly unstable ground, which risks disintegration at the moment when the concreteness and variety of situations of play are reintroduced. Once again, we are faced with the question of the type of knowledge which can be produced in the philosophy of technology, at the juncture between philosophy, psychology and anthropology.

\section{Systems of experience and philosophy of technical environments}

Our work Philosophie des jeux video was published in 2011. Its publication coincided with the breakthrough, mentioned earlier, in French-language video game studies. The text gave rise to several research projects 
typical of the recent recognition of the video game as a legitimate object of academic study.

The text nevertheless falls within the tradition of "philosophy of technical environments", to use the term which serves as the title of Jean-Claude Beaune's study (Beaune, 1999). This tradition is certainly the least known abroad, in comparison with the rediscovery of Simondon's work. Yet this tradition falls within the history of French philosophy of the second half of the twentieth century, in the wake of the considerable influence generated by Georges Canguilhem.

The term "technical environment" is borrowed from the sociology of work and anthropology. It first appeared in Leroi-Gourhan (1945) and Friedmann (1950) during the immediate post-war period. The philosophy of technical environments adopted the term for its own purposes from the 1970's onward, when its use in the social sciences was declining (Triclot, 2012). But the definitions of "technical environment" were not stabilized in Friedmann and Leroi-Gourhan. Friedmann uses "technical environment" as an antonym for "natural environment", whereas Leroi-Gourhan derives "technical environment" from the notion of "internal environment" in reference to the biological model of the cell. In other words, Friedmann opposes technique and nature while Leroi-Gourhan conceives of the terms as a continuity, according to the specifically stated project of a "biology of technicity".

Nevertheless, in each case, the notion of "technical environment" has the value of providing a framework for a "non-reductive technology", to use Beaune's expression : a technology which "removes the technical object from its exteriority" and analyzes the interlacing of technology and subjectivity which is characteristic of human existence. This is the starting point for Beaune's epistemological program : "Why does a technical object, the first utensil in our life and our being, cause such strange 'sensations'? Or, to put it differently, are we capable of stating clearly what makes this object original when it is considered in and of itself and above all when it is being used in the environment its presence creates, but which is often limited to the understanding we wish it to contain?” (Beaune, $1999: 7$ )

In this perspective, video games comprise a particularly remarkable field of study, insofar as they create a form of "instrumented experience" due to the use of machines, where "strange sensations", created by the interactive coupling of the computer and the screen, can be cultivated for themselves. But the epistemological problem, as recognized by Beaune himself, is to know how to objectify the subjectivation processes at work throughout the technical environment. Beaune, for his purposes, uses techniques which belong to literature, to the art of writing, giving life to the rhythms and time-spaces of the environment. But here we are dealing with a question which concerns the work of Perény, Koster and Boyer as well, and which is resolved alternatively by the notion of "coupling", by accounts of experience thanks to qualitative interviews, or by the phenomenological analysis of perception.

The philosophy of technical environments takes us down a historicist path. In Philosophie des jeux video, this path is embodied in the concept of "systems of experience", which aims to describe the different modes of involvement which have developed out of computer games. The notion itself is borrowed from a certain theory of cinema, which attempts to characterize the experience of the spectator in the movie theater rather than to decode the meaning of the films, in the tradition begun by Christian Metz (Metz, 1978; Bellour, 1999). Metz spoke about what he called "systems of desire" to designate the forms of contact between the subject in the movie theater and the cinematographic apparatus.

One of the central theses of the philosophy of video games is that the forms of experience which are given priority by the games depend on the environments in which they are played. The shift from the university environment, in the 1960's and 70's, to the arcade, in the 70's and 80's, provides a paradigm of this change. From an experience centered on "the total control over a simulated universe" characteristic of universitydeveloped games, we move to an experience of "loss of control", of "mechanical vertigo" in the arcades. Each of these experiences mirrors the properties of its environment : Spacewar, the first video game, replays the issue of the control of air space, developed from the military apparatus of the SAGE anti-air defense program, with a requirement for complete mastery and visibility. On the contrary, arcade games borrow the vertiginous logic, the pleasure of near-accidents, the adrenaline rush of violently accelerating vehicles, from mechanical fun fair systems.

But how can these transfers between environment and systems of experience be described? Rather than defining a domain reserved for philosophy, which would be the transcendental domain - but where it is difficult to find the empirical data without betraying it - , the philosophy of environments, whether that advocated by Beaune or by Leroi-Gourhan, promotes a style of necessarily incomplete analysis. "Analyses 
of a single object can thus be infinite : it means decomposing the simple act in which the interior environment participates wholly”. (Leroi-Gourhan, 1964 : 343).

This incompleteness argues in favor of a better relationship between the philosophy of technology, the humanities, and the social sciences. Philosophy is not condemned to a unique strategy of general explanations towards the decrypting of intentional attitudes. On the subject of game studies, this was, for example, Henriot's strategy, with the aim of studying play as a structure of consciousness in the manner of Sartre's famous analysis of self-deception (Triclot, 2014). But philosophy can also be closely involved with the empirical, in order to invent modes of inquiry concerning what is at issue in the details of the situations.

From this point of view, video games provide an ideal object. Indeed, they permit the collecting of a considerable number of recordings and traces, which cannot be easily decoded. We have thus been able to work on an analysis of filmed game sessions, which give rise to procedures of "phenomenographical" recoding in the search for inflections in the modes of presence (Piette) as well as to forms of rhythm analysis based on input capture on game controllers which reveal the manner in which the demands of the game apparatus are modulated by the players (Boutet, Carjaval, Ter Minassian, Triclot, 2013).

The positioning which stems from the concept of "technical environment" thus allows for an alliance with strategies of observation of a pragmatist-inspired anthropology, such as they are typically represented in the French-language context in the work of Manuel Boutet (Boutet, 2006, 2012). The philosophy of "technical environments" shares with this tradition not only the central reference to Leroi-Gourhan but also an attention to the production of lived experiences, everyday life, and the gestural and rhythmical dimension of activities, rather than mere symbolic and language-based investments. This alliance thus opens out new technical and conceptual possibilities with which to analyze the "strange sensations" of the environment and to pursue the infinite inquiry along new lines.

\section{Conclusion}

In conclusion, we have examined the role played by the philosophy of technology in the field of Frenchlanguage studies devoted to video games. We have tried to show the diversity of approaches and theoretical positions in a context dominated by the question of play, of forms of experience, and of coupling with machines. The use of philosophical references thus appears as representative of the major tendencies in French-language "game studies".

Philosophies of technology operate within this area of inquiry, difficult to negotiate, at the junction between subjects and their devices, but also between philosophy and the humanities and social sciences. While their main role can be seen as the application of a "theoretical framework" from which an ontology or ready-touse modes of description can be expected, the video game object nevertheless brings a particular intensity to the question of the relationship between the subject and the device. In this sense, the video game can be seen as a "technical environment" in miniature where, to use Jean-Claude Beaune's beautifully-phrased description, "a technical environment is first and foremost a place where we play out our lives and thought with our bodies, in successive degrees and osmoses, on the borderline between nature and artifice where we balance incessantly like dancers on a tightrope” (Beaune, 1999: 11).

\section{References}

Aarseth, E. (2001). Computer Game Studies, Year One. Game Studies, 1-1.

Amato, E.A. (2008). Le jeu vidéo comme dispositif d'instanciation : du phénomène ludique aux avatars en réseau, Thèse de doctorat en Sciences de l'Information et de la Communication, Université de Paris 8

Amato, E.A., Gaon, T., Boutet, M. (2011), " Games Studies ? à la française ! ", Appel à Communications. http://manuel.boutet.free.fr/GSALF2011.pdf. Accessed 18 Oct 2015.

Amato, E.A., Pereny E. (2008). Comment le premier cybermédium a pu un temps échapper aux SIC ?. $16^{e}$ Congrès de la Société Française des Sciences de l'Information.

Amato, E.A., Pereny, E. (2010). L'heuristique de l'avatar : polarités et fondamentaux des hypermédias et des cybermédias. Revue des Interactions Humaines Médiatisées, 11(1), 87-115.

Amato, E.A., Pereny, E. (2011). De l’Image interactive au Jeu vidéo : rétro-prospective des transversalités d'un objet cybernétique. Communication Game Studies ? A la française !.

Audureau, W. (2014), Pong et la mondialisation, Châtillon: Pix'n Love.

Auray, N., Craipeau, S. (2003). Les jeux en ligne, Les cahiers du numérique, vol. 4, 2.

Barboza, P., Weissberg, J-L., (2006). L’image actée. Paris: L’Harmattan. 
Beaune, J.C. (1999). Philosophie des milieux techniques. Seyssel: Champ Vallon

Bellour, R. (2009). Le corps du cinéma : Hypnoses, Émotions, Animalités. Paris: P.O.L.

Berry, V. (2012). L'expérience virtuelle. Rennes: PUR.

Berry, V., Coavoux, S., Rufat, S., Ter Minassian, H. (2013) Qui sont les joueurs de jeu vidéo en France ?. In Lejade, O., Triclot, M. (Ed.). La fabrique des jeux vidéo (pp. 172-177). Paris: La Martinière.

Blanchet, A. (2010). Des Pixels à Hollywood. Châtillon: Pix'n Love.

Boellstorff, T. (2008). Coming of Age in Second Life : An Anthropologist Explores The Virtually Human. Princeton: Princeton University Press.

Bogost, I. (2010). Persuasive Games: The Expressive Power of Videogames. Cambridge: MIT Press.

Boutet, M. (2006). De l'ordinateur personnel aux communautés en ligne. S'orienter dans les mondes informatiques. Thèse de doctorat en sociologie, sous la direction de Bernard Conein et Isaac Joseph, soutenue le 13 décembre 2006 à l’Université de Nice - Sophia Antipolis.

Boutet, M. (2012). Jouer aux jeux vidéo avec style. Pour une ethnographie des sociabilités vidéoludiques. Réseaux, $\mathrm{n}^{\circ} 173-174,207-234$.

Boutet, M., Carvajal, I., Ter Minassian, H., Triclot, M. (2013). Au-delà du virtuel : interactions sociales et spatiales dans et autour d'un univers vidéoludique . Revue MEI, 37, 103-116.

Boyer, E. (2015). Le conflit des perceptions. Paris: MF.

Boyer, E. (dir.) (2012). Voir les jeux vidéo : Perception, construction, fiction. Paris: Bayard.

Brougère, G. (2003). Jouets et compagnie. Paris: Stock.

Bruno, P. (1993). Les Jeux vidéo. Paris: Syros.

Caillois, R. (1958). Les hommes et les jeux. Paris: Gallimard.

Chateau, J. (1946). Le jeu de l'enfant. Paris: Vrin.

Coavoux, S., Rufat, S., Ter Minassian, H. (2014). Jouer aux jeux vidéo en France. Géographie sociale d'une pratique culturelle. Espace géographique, 43-4, 308-323.

Donovan, T. (2010). Replay: The History of Video Games. Lewes: Yellow Ant.

During, E. (2006). Simondon au pied du mur. Critique, 706, mars.

Frasca, G. (2003). Ludologists Love Stories, too. In Copier, Raessens (ed.), Level Up, DIGRA Research Proceedings, Utrecht

Friedman, G. (1950). Où va le travail humain ?. Paris:Gallimard.

Genvo, S. (2006). Le game design de jeux vidéo : approche communicationnelle et interculturelle. Thèse de doctorat en SIC, Université de Metz

Genvo, S. (2013). Penser les phénomènes de ludicisation à partir de Jacques Henriot. Sciences du jeu, 1.

Guchet, X. (2005). Les Sens de l'évolution technique. Paris:Léo Scheer.

Henriot, J. (1969). Le jeu. Paris: PUF.

Henriot, J. (1989). Sous couleur de jouer. Paris: Corti.

Jull, J. (1998). A Clash Between Game and Narrative. Digital Art and Culture Conference, Bergen, Norway

Jull, J. (2005). Half-Real: Video Games between Real Rules and Fictional Worlds. Cambridge: MIT Press.

Koster, R. (2013). Le jeu vidéo comme manière d'être au monde, Socio-anthropologie de l'expérience vidéoludique. Thèse de doctorat, Université Paris I.

Leroi-Gourhan, A. (1945). Milieu et technique. Paris: Albin Michel.

Leroi-Gourhan, A. (1964). Le geste et la parole, Tome 1. Paris: Albin Michel.

Mabillot, V. (2000). Les mises en scène de l'interactivité : représentations des utilisateurs dans les dispositifs de médiations interactives, Thèse de doctorat en SIC, Université de Lyon 2.

Metz, C. (1978). Le signifiant imaginaire. Paris: Bourgois.

Montfort, N., Bogost, I. (2009). Racing the beam. Cambridge: MIT Press.

Natkin, S. (2004). Jeux vidéo et médias du XXIe siècle : quels modèles pour les nouveaux loisirs numériques ?. Paris: Vuibert.

Pereny, E. (2013). Images interactives et jeu vidéo : de l'interface iconique à l'avatar numérique. Paris: Questions Théoriques.

Quezorla, J., Verebely, F. (1983). Jeu, image et communication. Réseaux, 1, 3-17.

Rueff, J. (2008). Où en sont les Game Studies ?. Réseaux, 5, 151, 139-166.

Rufat, S., Ter Minassian, H. (2012). Les jeux vidéo comme objet de recherche. Paris: Questions Théoriques.

Servais, O. (2013). De l'ethnologie missionnaire à l'anthropologie prospective du virtuel, Histoire, monde et cultures religieuses, 2-26, 95-108.

Sidre, C. (2014). L'objet vidéoludique et ses réseaux de distribution (1974-1988). Thèse de l’École Nationale des Chartes.

Simondon, G. (1958). Du mode d'existence des objets techniques. Paris: Aubier.

Tayor, T.L. (2006). Play between Worlds : Exploring Online Game Culture. Cambridge: MIT Press.

Tremel, L. (2001). Jeux de rôles, jeux vidéo, multimédia. Les Faiseurs de mondes. Paris: PUF.

Triclot, M. (2011). Philosophie des jeux vidéo. Paris: La découverte. 
Triclot, M. (2012). Jouer au laboratoire : le jeu vidéo à l'université (1962-1979). Réseaux, 30, 173-174, 177205.

Triclot, M. (2012). Milieu technique : généalogie d'un concept. In Parrochia, Tirloni (Ed.), Formes, Systèmes et Milieux Techniques, Jacques André.

Triclot, M. (2013). Super Mario rentre au musée. Le monde diplomatique, dec., 20-21.

Triclot, M. (2014). Game studies ou études du play ? Une lecture croisée de Jacques Henriot et de Jesper Juul. Sciences du jeu, 1.

Weizenbaum, J. (1976). Computer Power and Human Reason. San Fransisco: Freeman.

Wendling, T. (2010). Une joute intellectuelle au détriment du jeu ? Claude Lévi-Strauss vs Roger Caillois (1954-1974). Ethnologies, 32-1, 29-49.

Zabban V. (2012). Retour sur les Game Studies. Réseaux, 30, 173-174, 141-176. 